\title{
液体窒素温度と室温で予ひずみを与えた後の液体窒素温度と室温 での繰返し変形挙動
}

\author{
横 塚 智 人 $^{*}$ 池上皓 三** \\ Cyclic Plastic Deformation at Low Temperature in Liquid Nitrogen and \\ Room Temperature Subsequent to Pre-Strain at Low Temperature \\ in Liquid Nitrogen and Room Temperature
}

\author{
by \\ Tomohito Yokotsuka * and Kozo Ikegami **
}

\begin{abstract}
Cyclic loading tests are performed by using thin-walled tubular specimens of SUS304 stainless steel at low temperature in liquid nitrogen $(77 \mathrm{~K})$ and room temperature. Cyclic plastic deformation subsequent to pre-strain at $77 \mathrm{~K}$ and room temperature is experimentally investigated under torsional, tensile and compressive loading conditions. At small cyclic numbers, the pre-strain perpendicular to cyclic loading direction results in large hardening, and cyclic plastic behavior subsequent to the pre-strain at $77 \mathrm{~K}$ is more hardened than the pre-strain at room temperature. With increasing cyclic number, the effect of temperature on the hardening behavior becomes small. When the cyclic loadings are conducted in the same direction as the pre-straining direction, the effect of the pre-strain on hardening behavior is not remarkable at room temperature and $77 \mathrm{~K}$. The pre-strain at $77 \mathrm{~K}$ influences the cyclic hardening at room temperature even for large cyclic number.
\end{abstract}

Key words : Material testing, Plasticity, Low cycle deformation, Pre-strain, Cyclic loading

\section{1 緒言}

低温構造体の重要性が高まるにつれて, 低温構造材料 の変形特性の把握が必要となってきている．著者らは, これまでに低温での変形挙動について, 複雑な負荷, ${ }^{1)}$ 繰

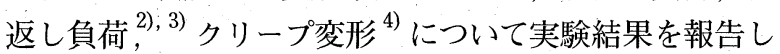
てきた。低温構造体は, 実用的には低温と室温の温度変 化と繰返し変形を受ける場合が多いことが予想される。 本報告では，低温構造体として広く使われている SUS304 鋼について，予ひずみを与えないときと，液体 窒素温度打よび室温で予ひずみを与えた後に, 繰返し変 形をそれでれ室温と液体窒素温度で行い, 予ひずみを与 えた温度と繰返し変形時の温度を変化させて, 予ひずみ の繰返し変形に及ぼす影響を調べた。

\section{2 試験装置および試験片}

本研究で使用した低温複合荷重材料試験機は，極低温 用に試作されたもの ${ }^{5}$ で, 室温から液体へリウム温度 （4.2K）まで試験することが可能である. 負荷形式は, 電 気油圧サーボ式を採用している。試験機上部の油圧トル クモータからねじり方向負荷を, 試験機下部の油圧シリ ンダより軸方向負荷を与えることができる。これらの負 荷は, 内側がねじり軸と外側が引張軸の二重円筒管を介 して，試験片に同時に加えることができる，試験片に加 わる軸方向荷重とねじり方向荷重は, 二重口筒管の内筒 の上部に取り付けたロードセルより測定し，ひずみは画
像処理法 ${ }^{6)}$ を用いて計測した。

試験機のアナログフィードバック系の制御は D/A 変換 器を介してパーソナルコンピュータによって行い, プロ グラムにより任意の負荷を試験片に与えることができる. ロードセルより測定した応力は, A/D 変換器を介してパ ーソナルコンピュータに取り込み, 記録する. 実験は, ロードセルによって測定した応力をフィードバック信号 とし, 応力速度を制御して行った。

試験片材料には，耐食性に優れ，低温に打いても高い 延性をもち，熱伝導率が小さく，入手することも容易な ため, 低温構造体として広く用いられているオーステナ イト系ステンレス SUS304 鋼を用いた。試験片形状は, 長さ $50 \mathrm{~mm}$, 外径 $9.6 \mathrm{~mm}$, 内径 $8.0 \mathrm{~mm}$ の薄肉円筒形状 である.この試験片は, 加工時の残留応力を除去して, 一様なオーステナイト組織をつくるため，アルゴンガス 中で $1050^{\circ} \mathrm{C}$ に加熱して, 30 分間保持し, その後空気中 で放冷する固溶体化熱処理を施した。

\section{3 実 験 方 法}

本研究では, 実験を液体窒素温度 (77K) と室温で行 った，負荷方法は，次のような手順である。

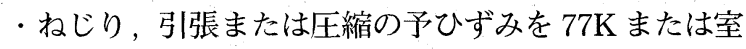
温で与え, 完全除荷する。

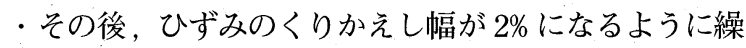
返し負荷を $77 \mathrm{~K}$ または室温で 40 サイクル行う. 
負荷速度は，真応力が $10 \mathrm{MPa} / \mathrm{sec}$ から $1 \mathrm{MPa} / \mathrm{sec}$ ま で順次変化する方法を用いた。弾性域とみなせる範囲は, 負荷速度が $10 \mathrm{MPa} / \mathrm{sec}$ で負荷し，塑性域ではひずみの 值によって順次，負荷速度が減少する負荷条件で行った. この過程を負荷速度とひずみの值の関係で示したのが Fig. 1 である. 点 $\mathrm{B}$ や点 $\mathrm{C}_{1}$ などの記号は, Fig. 2 と対 応している．また，Fig. 1のひずみの值は，予ひずみを 与えた後, 完全除荷したときのひずみの值を 0 として負 荷中のひずみの值を示したものである.

本研究では, 繰返し中の応力ーひずみ曲線の特徴を調 べるため, 応力幅 $\Delta \sigma$ と累積塑性ひずみ $S^{P}$ を用いる。こ れらの值をFig. 2 に示す. 罒の実線は繰返し中の応力一 ひずみ曲線で, これらを相当応力一相当ひずみの関係で 示したのが破線である. まず, 点 0 から点 A と予ひずみ を与え，その後，完全に除荷し点 $\mathrm{B}$ に達する。この点 $\mathrm{B}$ から $\mathrm{C}_{1} \rightarrow \mathrm{D}_{1} \rightarrow \mathrm{C}_{2} \rightarrow \mathrm{D}_{2} \rightarrow \cdots$ と繰返し試験を行う. こ のとき，それまで繰返し負荷で生じた塑性ひずみを横軸 方向に累加した相当ひずみ量が累積塑性ひずみ $S^{P}$ であ る.すなわち,この曲線を点 $\mathrm{D}_{1}$ を中心 $180^{\circ}$ 回転移動 をすれば, $\mathrm{C}_{1} \rightarrow \mathrm{D}_{1} \rightarrow \mathrm{C}_{2}{ }^{\prime} \rightarrow \mathrm{D}_{2}{ }^{\prime} \rightarrow \cdots$ のように横軸が累 積塑性ひずみになる。また, 繰返し負荷を与えていると き, あるサイクルでの最大応力值 (点 $\mathrm{C}_{1}$ の応力值) と 最小応力值 $\left(\mathrm{C}_{2}\right.$ の応力值) の差が応力幅 $\Delta \sigma$ とする．な お，塑性のひずみ幅 $\Delta S^{P}$ は，ねじり負荷の場合には塑性

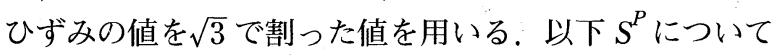
も同様である。

\section{4 実験結果と考察}

\section{$4 \cdot 1$ ねじり方向繰返しにおける予ひずみの温度の影響}

予ひずみを与えて, ねじり方向繰返し負荷を与えたと きの応力ーひずみ線図の例を Fig. $3^{3)}$ に示す。これは，

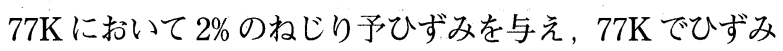
幅が $2 \%$ になようにねじり方向繰返し負荷を与えたと きの応力ーひずみ曲線である. 繰返し数の小さいところ では, ヒステリシスループのひずみ方向の幅が広いが, 繰返し数が大きくなると，ひずみ方向の幅が狭くなり， 応力方向に細長くなる。これは, 繰返し負荷により, 材 料が硬化したためである。この硬化の進行を見るために， Fig. 2 で示した応力幅と累積塑性ひずみを用いた. なお 予ひずみをあたえたときには，その值も累積塑性ひずみ の值に含めた。

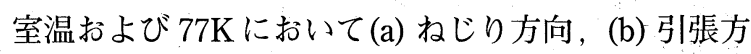
向, (c) 圧縮方向の予ひずみを $2 \%$ 与えた後, $77 \mathrm{~K}$ でねじ り方向繰返し負荷を与えたときの応力幅一累積塑性ひず 夕曲線を Fig. 4 (a), (b), (c) に示す。これらの図には, 予ひずみを与えずにねじり方向の繰返し変形を行った試 験の結果も示してある。なお，累積塑性ひずみの值には 予ひずみ量も含んでいる．Fig. 4 (a) のねじり方向予ひ ずみを与えた場合，予ひずみを与えずに繰返した場合と， $77 \mathrm{~K}$ で予ひずみを与えた場合の硬化量はほぼ同じであり， 室温で予ひずみを与えた場合が約 $5 \%$ 程硬化量が少ない. Fig. 4 (b)，(c) の引張，圧縮方向予ひずみを与えた場 合, すなわち, 繰返し方向と $90^{\circ}$ 方向の予ひずみを与え

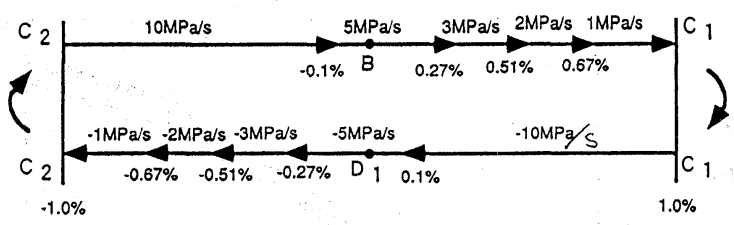

Fig. 1. Cyclic loading conditions.

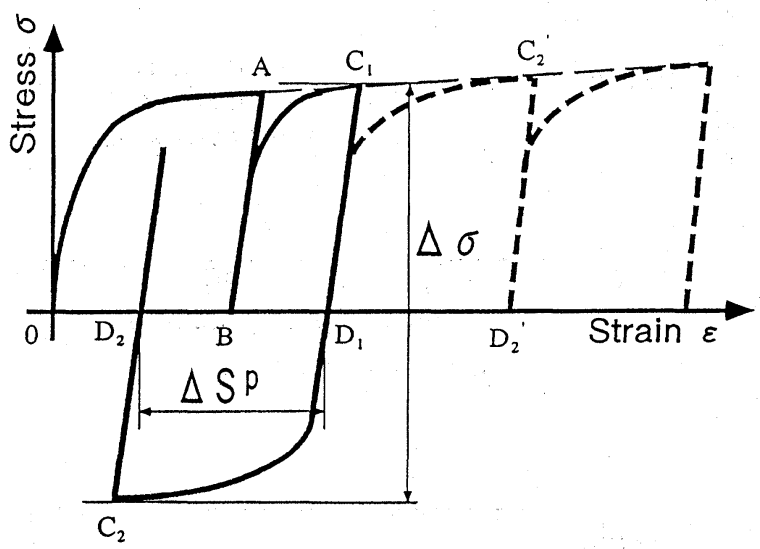

Fig. 2. Parameters of cyclic stress-strain curves.

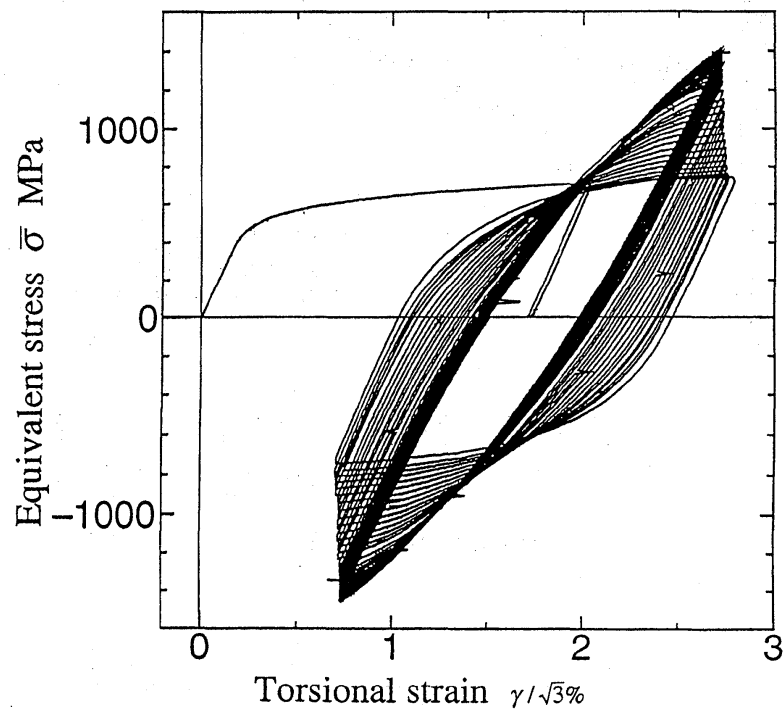

Fig. 3. Stress-strain curve of cyclic torsional test subsequent to torsional pre-strain at $77 \mathrm{~K}^{3)}$

た場合は， $77 \mathrm{~K}$ で予ひずみを与えた場合が，室温で予ひ ずみを与えた場合や予ひずみを与えない場合と比べ，繰 返し回数の少ないところで硬化量が大きい.

そして，室温でも引張や圧縮方向予ひずみを与えた場 合は, 繰返し回数の少ないところで，予ひずみを与えな

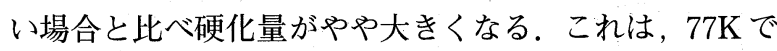
の単純負荷において負荷方向を $90^{\circ}$ 折り曲げた場合に大 きな硬化が見られる ${ }^{1)}$ のと類似の現象である。しかし， 繰返し回数が多くなり累積塑性ひずみが大きくなると, $77 \mathrm{~K}$ での繰返し変形では，予ひずみの方向と与える温度 の影響が小さくなり，ほぼ 1 つ曲線に収束していく.

室温で予ひずみを与えても，その後の繰返し変形挙動 に影響が出ていることから, 室温で, ねじり，引張，厷

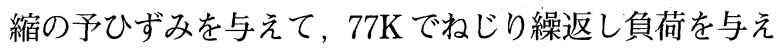




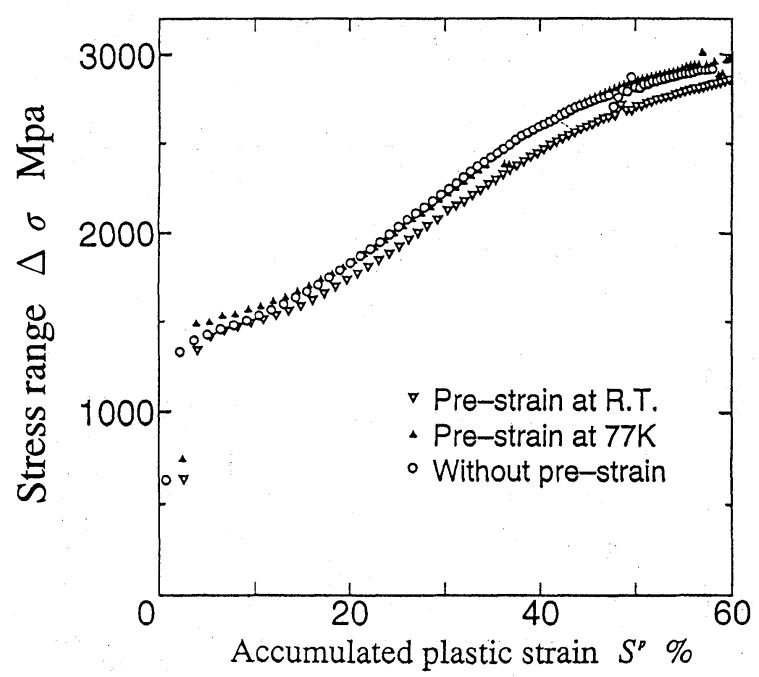

(a) Torsional pre-strain

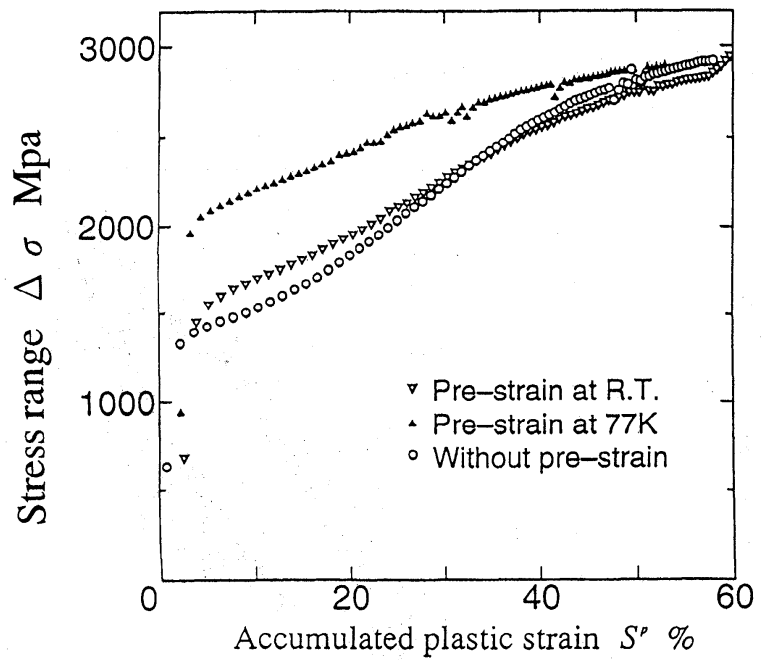

(b) Tensile Pre-strain

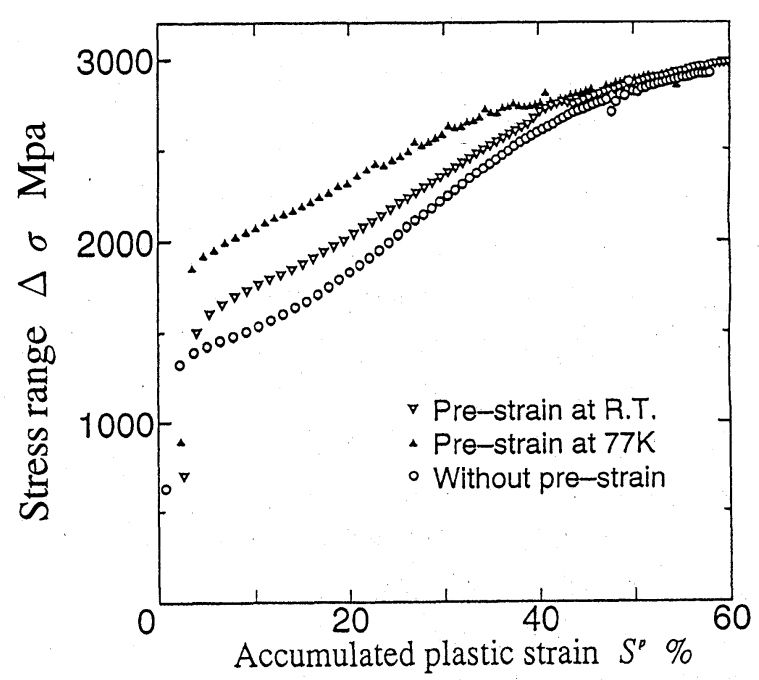

(c) Compressive pre-strain

Fig. 4. Effect of pre-straining temperature on cycle torsional test at $77 \mathrm{~K}$.

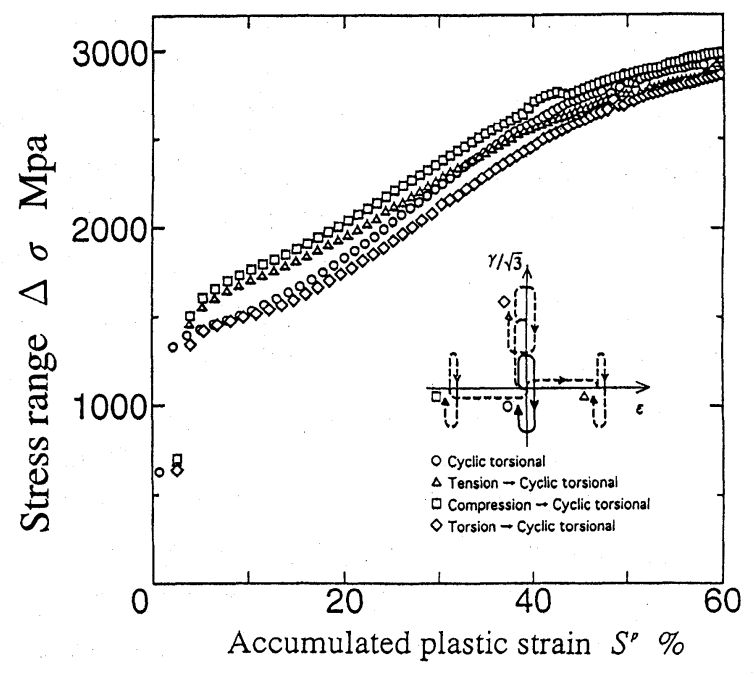

Fig. 5. Relation between stress range and accumulated plastic strain of cyclic torsional test at $77 \mathrm{~K}$ subsequent to pre-strain at room temperature.

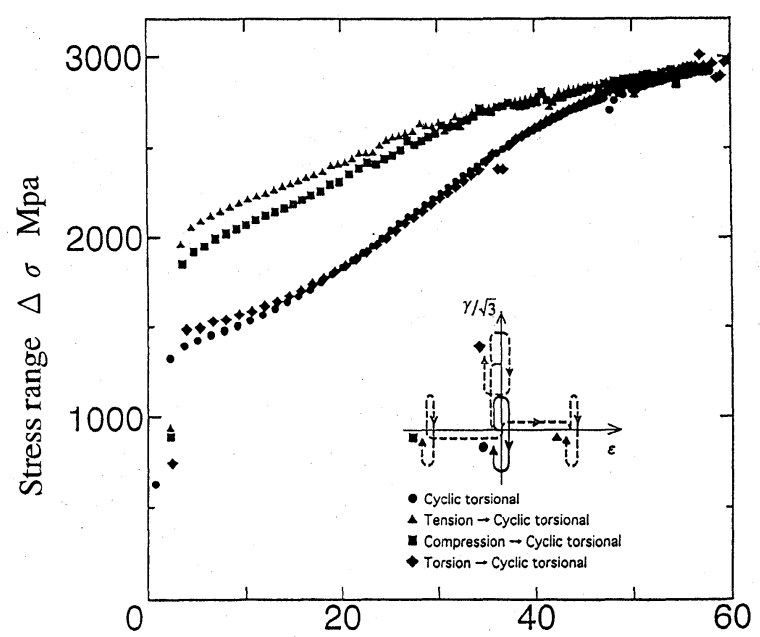

Accumulated plastic strain $S^{p} \%$

Fig. 6. Relation between stress range and accumulated plastic strain of cyclic torsional test subsequent to torsional, tensile and compressive pre-strain at $77 \mathrm{~K}^{3)}$

たときの応力幅一累積塑性ひずみの関係を Fig. 5 に示

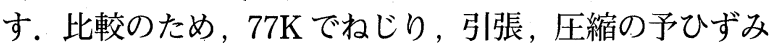
を与え, $77 \mathrm{~K}$ でねじり方向繰返し負荷を与えたときの応 力幅一累積塑性ひずみの関係を Fig. $6^{3)}$ に示す. 室温で 予ひずみを与えた場合は, $77 \mathrm{~K}$ で予ひずみを与えたほど の硬化は示さないが, 繰返しと $90^{\circ}$ 方向, すなわち引張 や圧縮方向に予ひずみを与えた場合は, 初期の段階で繰 返し方向と同方向の予ひずみを与えた場合に比べ硬化量 が大きく，累積塑性ひずみが $10 \%$ のところでは，ねじり 予ひずみを与えたものと比べ, 応力幅が約 1.15 倍になっ ている。

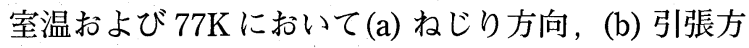
向, (c) 圧縮方向の予ひずみを与えた後, 室温でねじり 方向繰返し負荷を与えたときの応力幅一累積塑性ひずみ 曲線を Fig. 7 (a)，(b)，（c）に示す. Fig. 7 (a)のねじり 


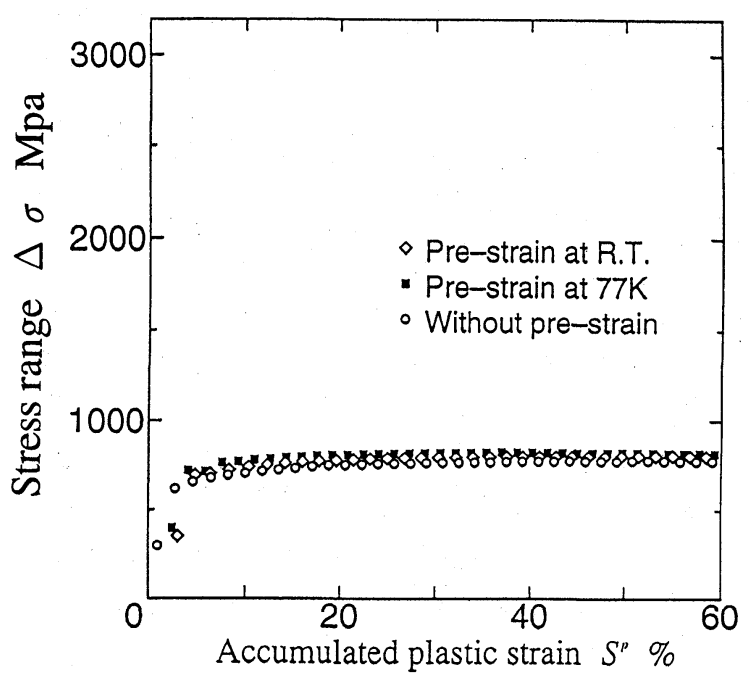

(a) Torsional pre-strain

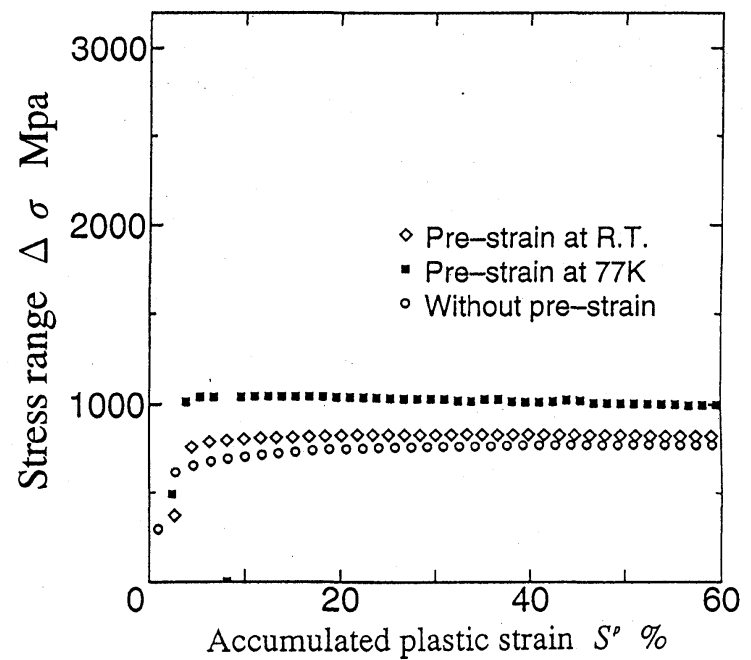

(b) Tensile pre-strain

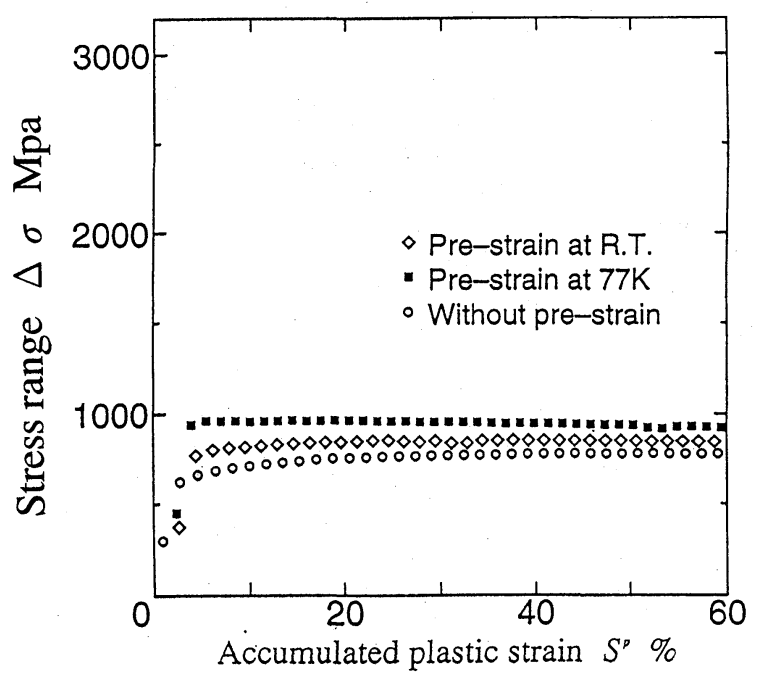

(c) Compressive pre-strain

Fig. 7. Effect of pre-straining temperature on cyclic torsional test at room temperature.
方向に予ひずみを与えた場合, 繰返し方向と同方向の予 ひずみを与えると，予ひずみを室温で与えても，77K で 与えてもほほ同じ変形挙動を示し, その変形挙動は累積 塑性ひずみの值が同じであれば予ひずみを与えないもの と同じである. Fig. 7 (b), (c) の引張, 圧縮方向に予ひ ずみを与えた場合, 室温で予ひずみを与えた場合と与え ない場合を同じ累積塑性ひずみの值で比較すると室温で の予ひずみの影響は, 低温での予ひずみの影響に比べて 小さい，累積塑性ひずみの值が同じであれば予ひずみを

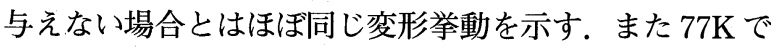
予ひずみを与えた場合は, 予ひずみを与えない場合と室 温で与えた場合と比べ, 硬化量が大きくなる傾向にある.

\section{4・2 軸方向繰返しにおける予ひずみの温度の影響}

予ひずみを与えて, 軸方向に繰り返したときの応力ーひ ずみ線図の例を Fig. $8^{3)}$ に示す。これは，77Kにおおて引 張予ひずみを $2 \%$ 与えて，ひずみの幅が $2 \%$ になるように 軸方向繰返し負荷を与えたときの応力ーひずみ曲線であ る. ねじり方向の繰返し負荷の場合と同様に, 繰返し数が 大きくなるとヒステリシスループのひずみ方向の幅が狭く なり, 応力方向に細長くなり, 材料が硬化している.

室温および77Kにおいて (a) ねじり方向，(b) 引張方 向，(c) 圧縮方向の予ひずみを与えた後， $77 \mathrm{~K}$ で軸方向 繰返し負荷を与えたときの応力幅一累積塑性ひずみの関 係を Fig. 9 (a)，(b)，(c) に示す。この図には，予ひず みを与えない場合のねじり方向の繰返し変形試験の結果 も示してある. Fig. 9 (a)のねじり方向予ひずみを与えた 場合， $77 \mathrm{~K}$ で予ひずみを与えた場合の硬化量が，室温で 予ひずみを与えた場合や予ひずみを与えない場合と比べ, 累積塑性ひずみが $30 \%$ 硬化量が大きい. 室温で予ひずみ を与えた場合も，77K で与えた場合ほどないが，硬化量

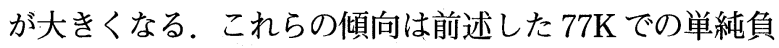
荷において負荷方向を $90^{\circ}$ 折り曲げた場合に大きな硬化 が現れるのと同様である.しかし, 繰返し回数が多くな り累積塑性ひずみが大きくなると, 予ひずみの方向と与

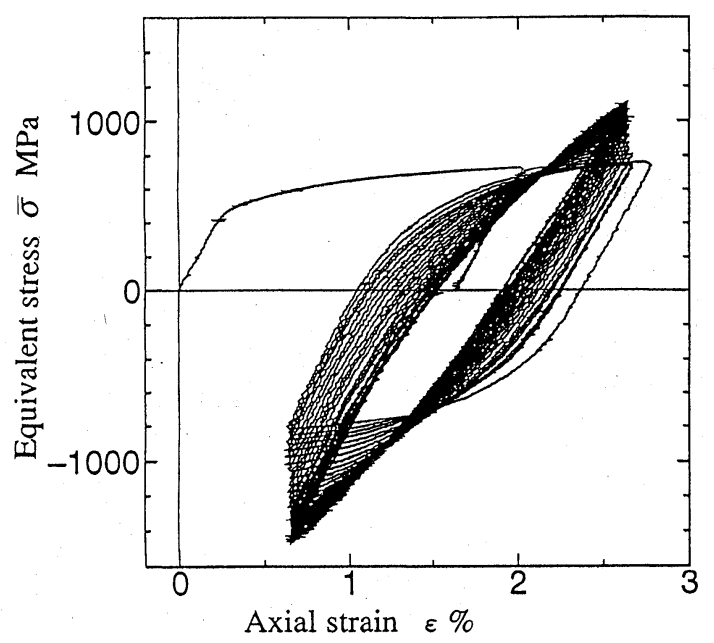

Fig. 8. Stress-strain curves of cyclic tensile and compressive test subsequent to tensile pre-strain at $77 \mathrm{~K}^{3)}$ 


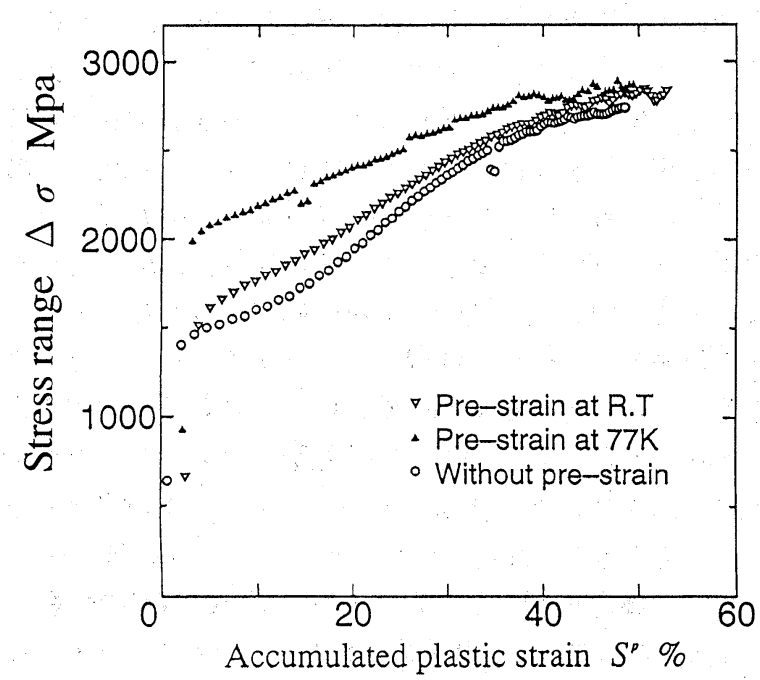

(a) Torsional pre-strain

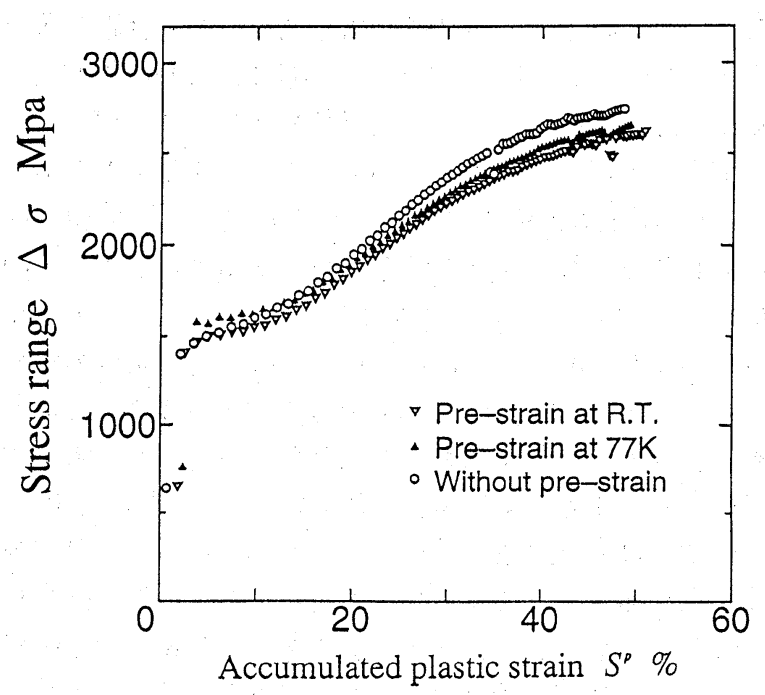

(b) Tensile pre-strain

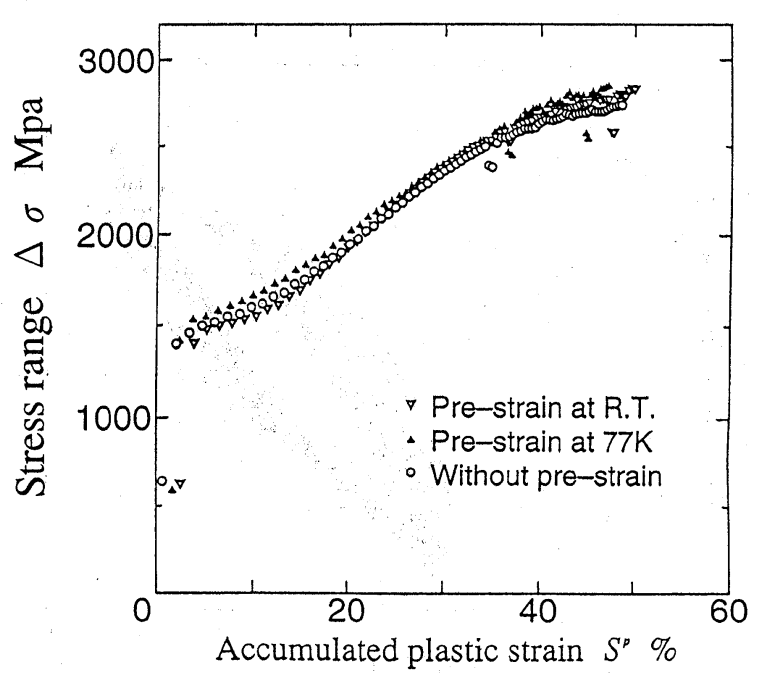

(c) Compressive pre-strain

Fig. 9. Effect of pre-straining temprerature on cyclic tensile and compressive test at $77 \mathrm{~K}$.
える温度の影響が小さくなる. Fig. 9 (b), (c) の引張, 圧縮方向予ひずみを与えた場合は，室温で予ひずみを与 えた場合と，77K で予ひずみを与えた場合の硬化量はほ ぼ同じであり，予ひずみを与えた温度の影響は小さい。

室温で, 引張，圧縮，ねじりの予ひずみを与えて $77 \mathrm{~K}$ で軸方向繰返し負荷を与えたときの応力幅一累積塑性ひ

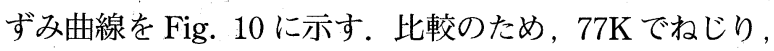
引張, 圧縮の予ひずみを与え, $77 \mathrm{~K}$ で軸方向繰返し負荷 を与えたときの応力幅一累積塑性ひずみの関係を Fig. $11^{3)}$ に示す. $77 \mathrm{~K}$ で予ひずみを与えた場合ほどではない が, 繰返しと $90^{\circ}$ 方向，すなわち，ねじり方向に予ひず みを与えた場合は, 繰返し回数の少ないところで繰返し 方向と同方向に予ひずみを与えた場合に比べ硬化量が大 きく，累積塑性ひずみが $10 \%$ のところでは，引張や圧縮 の予ひずみを与えた場合と比べ, 応力振幅が約 1.13 倍の

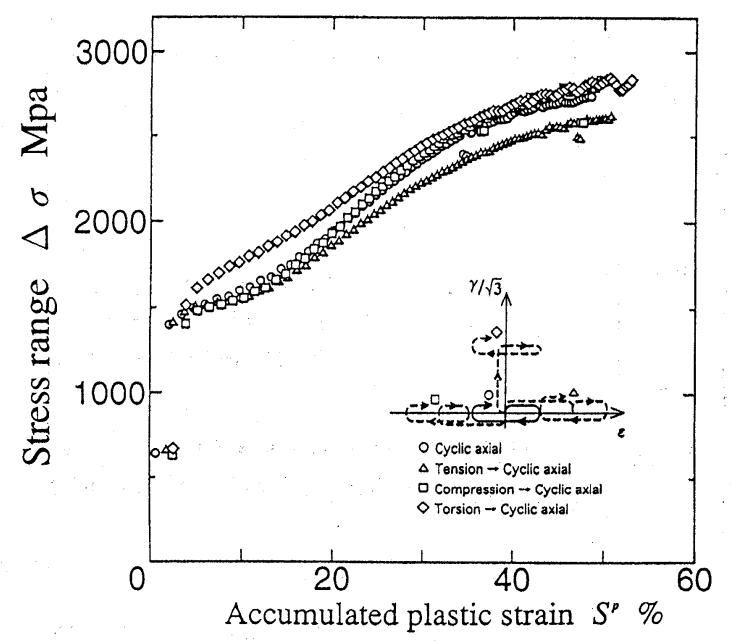

Fig. 10. Relation between stress range and accumulated plastic strain of cyclic tensile and compressive test at $77 \mathrm{~K}$ subsequent to pre-strain at room temperature.

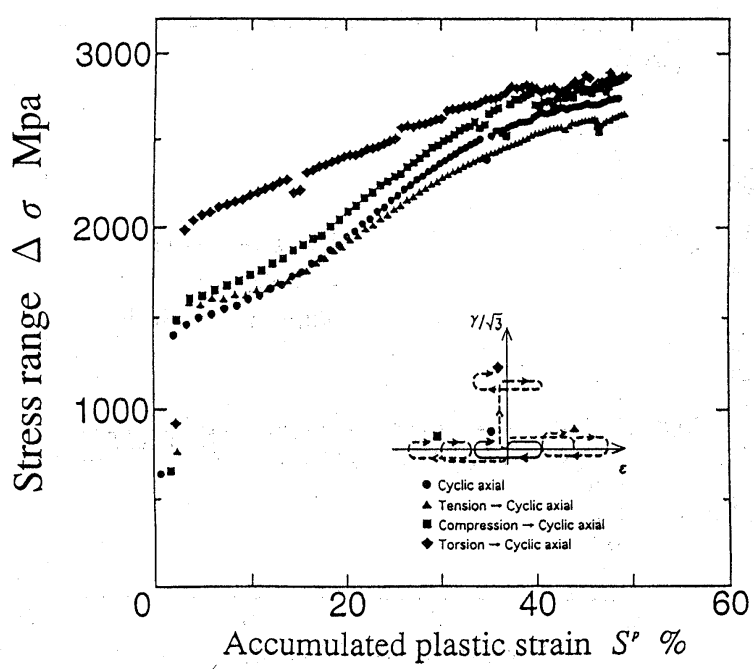

Fig. 11. Relation between stress range and accumulated plastic strain of cyclic tensile and compressive test subsequent to torsional, tensile and compressive pre-strain at $77 \mathrm{~K}^{3 \text { ) }}$ 


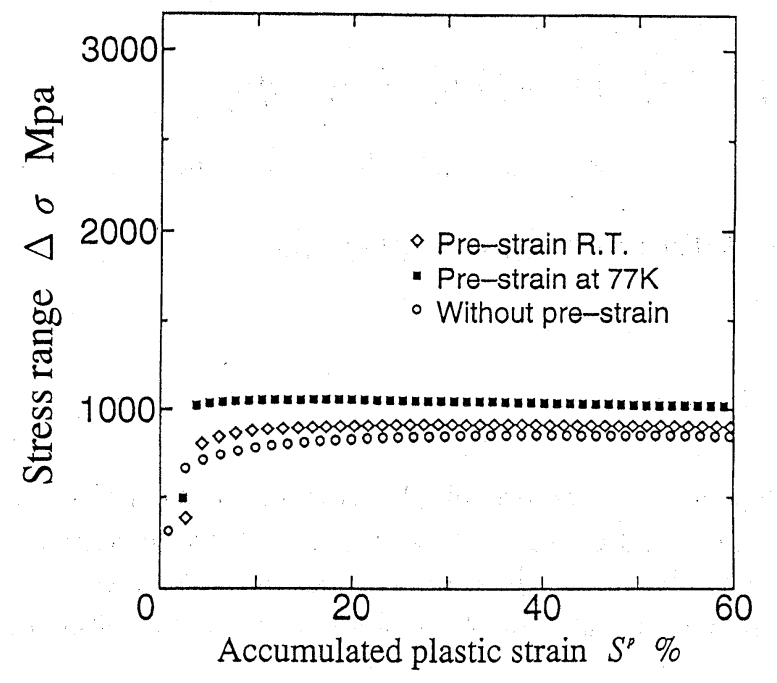

(a) Torsional pre-strain

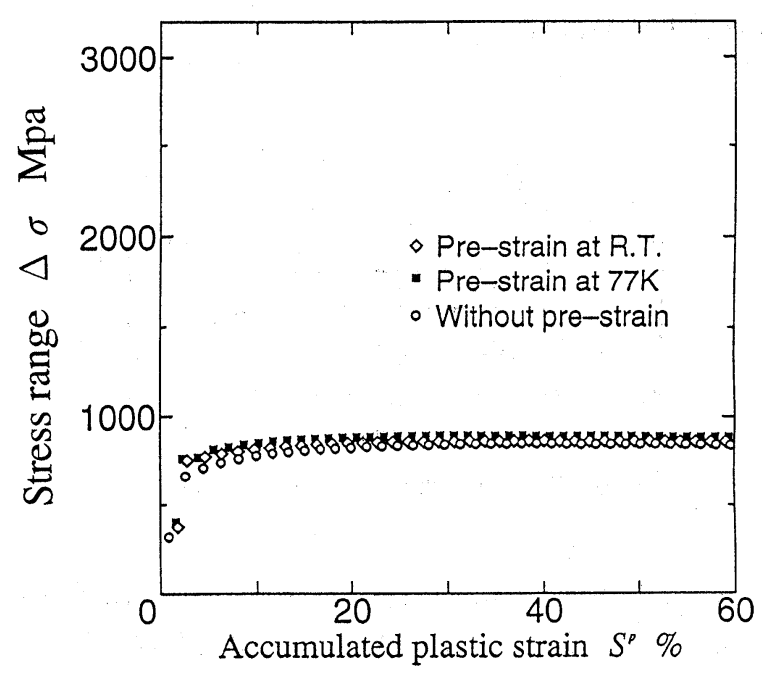

(b) Tensile pre-strain

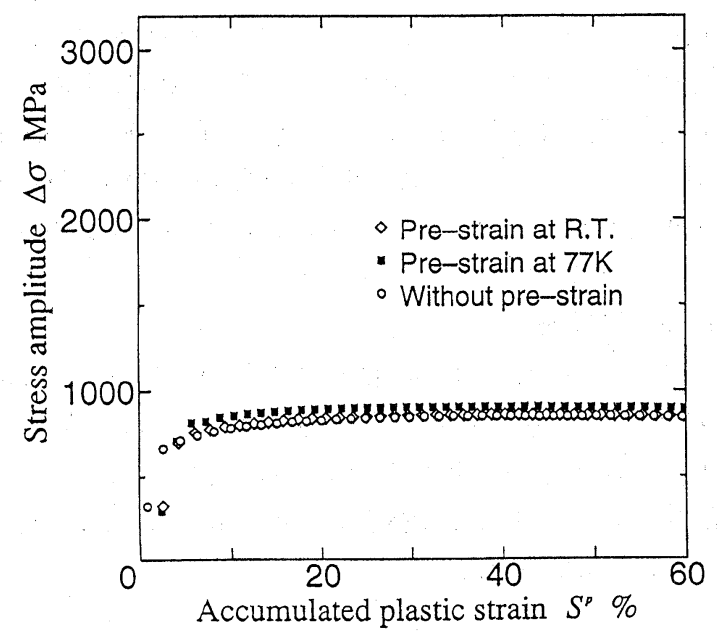

(c) Compressive pre-strain

Fig. 12. Effect of pre-straining temperature on cyclic tensile and compressive tests at room temperature.
值になっている，累積塑性ひずみが大きくなると，予ひ ずみが圧縮方向や, ねじり方向に与えた場合や与えない 場合の曲線がほぼ一致するが，引張方向に予ひずみを与 えた場合は, $77 \mathrm{~K}$ の予ひずみの場合と同様に硬化量が小 さくなる.

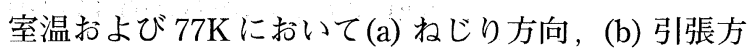
向, (c) 圧縮方向の予ひずみを与えた後, 室温で軸方向 繰返し負荷を与えたときの応力振幅一累積塑性ひずみ曲 線を Fig. 12 (a)， (b)，(c) に示す. Fig. 12 (a)のねじり 方向に予ひずみを与えた場合, 繰返し方向と $90^{\circ}$ 方向の 予ひずみを与えると，77K で予ひずみを与えた場合の硬 化量が大きくなり, 室温で予ひずみを与えた場合と予ひ ずみを与えない場合の変形挙動は累積塑性ひずみ量が大 きくなるに従い，予ひずみの影響は小さくなる．Fig. 12 (b), (c) の繰返し方向と同方向, すなわち引張, 圧縮 方向に予ひずみを与えた場合は，予ひずみを室温や $77 \mathrm{~K}$ で与えても，与えなくてもその硬化量は，ほぼ同じにな り予ひずみを与えた温度の影響は小さい.

\section{5 結言}

$77 \mathrm{~K}$ と室温におけるステンレス鋼 SUS304 の繰返し変 形挙動に対して, 予ひずみの及ぼす影響について実験的 に調べた。実験は, 液体窒素中, または室温の大気中で 薄肉円筒試験片に予ひずみを与えた後, ねじり，または 引張圧縮の繰返し変形を行い, 予ひずみが繰返し変形中 の応力ーひずみ曲線に与える影響を調べた。 繰返し変形 挙動を調べるために, 繰返し応力一ひずみ曲線の応力振 幅と, 予ひずみ扎よび繰返し変形によって生ずるひずみ を加えた累積塑性ひずみの関係を用いた。

(1) 繰返し方向と垂直な予ひずみは, 室温で与えるよ り $77 \mathrm{~K}$ で与える方が繰返し負荷による硬化量が大きくな る.しかし, 繰返し回数が多くなると, 予ひずみを与え るときの温度の影響は小さくなる。

（2）室温で繰返し負荷を行う場合, 繰返し方向と垂直 方向の予ひずみを $77 \mathrm{~K}$ で与えると, 繰返し回数が多くな っても予ひずみの影響は残る。

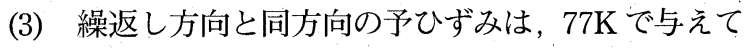
も, 室温で与えても, その後の繰返し変形に大きな影響 を与えず，予ひずみを与えない場合の繰返し変形とほぼ 同じ挙動を示す。

\section{考文 献}

1) 田中直敬, 白沢 洋, 池上皓三, 日本機械学会論文集, A57, 2775 (1991).

2 ) 白沢 洋, 池上皓三, 新津 靖, 日本機械学会論文集, A59, 2427 (1993).

3 ）横塚智人, 池上皓三, 日本機械学会論文集, A-64, 209 (1998).

4 ) 河合出穂, 池上皓三, 新津 靖, 日本機械学会論文集, A62, 2319 (1996).

5 ) 辻 大作, 新津 靖, 池上皓三, 日本機械学会論文集, A53, 1426 (1987).

6 ) A. Horiguti, Y. Niitsu and K. Ikegami, Proc. of int. conf. on Advanced Mechatro, 489 (1989). 